\title{
PENERAPAN MODEL PEMBELAJARAN GUIDED INQUIRY UNTUK MENINGKATKAN AKTIVITAS DAN HASIL BELAJAR KIMIA DI KELAS X MIPA
}

\author{
Ni Made Susanti, ${ }^{*}$ I Nyoman Suardana ${ }^{2}$, Made Suwenten ${ }^{3}$ \\ 1 Universitas Pendidikan Ganesha \\ 2Universitas Pendidikan Ganesha \\ ${ }^{3}$ SMA Negeri 3 Singaraja
}

\begin{abstract}
Abstrak
Penelitian tindakan kelas ini bertujuan untuk meningkatkan aktivitas dan hasil belajar kimia siswa melalui model pembelajaran guided inquiry. Penelitian dilakukan di kelas X MIPA 4 SMA Negeri 3 Singaraja semester Ganjil Tahun Pelajaran 2016/2017. Jumlah peserta didik sebanyak 28 terdiri atas 12 peserta didik laki-laki dan 16 peserta didik perempuan. Penelitian berlangsung selama dua siklus. Tiap siklus terdiri atas kegiatan perencanaan, pelaksanaan, pengamatan, dan refleksi. Tiap siklus terdiri atas empat kali pertemuan dan setiap pertemuan berlangsung $3 \times 45$ menit. Pada siklus I difokuskan pada materi struktur atom Bohr dan sistem periodik unsur. Pada siklus 2 difokuskan pada materi ikatan kimia. Data-data dalam penelitian ini berupa data kuantitatif yang diperoleh melalui hasil evaluasi tiap akhir siklus. Selain itu juga berupa data kualitatif yang diperoleh melalui hasil observasi. Berdasarkan analisis data diketahui bahwa telah terjadi peningkatan aktivitas belajar kimia dan peningkatan hasil belajar kimia siswa. Hasil belajar dari kondisi awal ke kondisi akhir mengalami peningkatan. Nilai rerata yang dicapai peserta didik pada kondisi awal sebesar 55,50 menjadi 68 pada siklus I dan meningkat menjadi 78,00 pada siklus II sehingga dari kondisi awal ke kondisi akhir peningkatan nilai rerata peserta didik sebesar 22,5\%. Jumlah peserta didik yang mencapai kriteria ketuntasan minimal (KKM) dari kondisi awal ke kondisi akhir mengalami peningkatan. Jumlah peserta didik yang mencapai KKM pada kondisi awal sebanyak 8 peserta didik atau sebesar 27,5\% menjadi 16 peserta didik atau sebesar $57 \%$ pada siklus I dan meningkat menjadi 28 peserta didik atau sebesar $100 \%$ pada siklus II. Dengan demikian dari kondisi awal ke kondisi akhir peningkatan jumlah peserta didik yang mencapai KKM sebesar $72,5 \%$.
\end{abstract}

\author{
Kata-kata kunci: \\ guided inquiry, aktivitas \\ belajar kimia, hasil belajar \\ kimia
}

\section{Pendahuluan \\ Ilmu kimia adalah cabang ilmu} pengetahuan alam yang mempelajari struktur materi, sifat-sifat materi, perubahan suatu materi menjadi materi lain, serta energy yang menyertai perubahan materi (Sirhan, 2007). Hakikat ilmu kimia mencakup dua hal, yaitu kimia sebagai produk dan kimia sebagai proses. Kimia sebagai produk meliputi sekumpulan pengetahuan yang terdiri atas fakta-fakta, konsep-konsep, dan prinsip-prinsip kimia. Kimia sebagai proses meliputi keterampilanketerampilan dan sikap-sikap yang dimiliki oleh para ilmuwan untuk memperoleh dan mengembangkan pengetahuan kimia. Oleh sebab itu, pembelajaran kimia harus memperhatikan hakikat ilmu kimia sebagai proses dan produk (Depdiknas, 2006). Salah satu tujuan pembelajaran ilmu kimia di SMA adalah agar siswa

memahami konsep-konsep kimia dan saling keterkaitanya serta penerapanya dalam kehidupan sehari-hari maupun teknologi. Namun beberapa siswa sering mengalami kesulitan dalam memahami konsep kimia menyebabkan hasil belajar siswa pada mata pelajaran tersebut rendah. Hasil belajar siswa rendah dapat dilihat dari nilai ulangan umum pada mata pelajaran kimia kelas XI semester genap tahun ajaran 2015/2016 berdasarkan observasi lapangan yang dilakukan oleh peneliti di kelas X MIPA 4 SMA Negeri 3 Singaraja, yaitu persentase ketuntasan siswa terhadap nilai ulangan umum kimia kurang dari 50\% siswa, dengan Kriteria Minimal Ketuntasan (KKM) tersebut yaitu 70 .

Kegiatan pembelajaran kimia di SMA Negeri 3 Singaraja masih menggunakan model 
dan pendekatan pembelajaran yang konvensional. Berdasarkan pengalaman peneliti, dalam proses belajar mengajar kimia yang berlangsung di SMA Negeri 3 Singaraja, siswa relatif pasif menerima dan mengikuti apa yang disajikan oleh guru, rendahnya semangat belajar siswa, bahkan tidak jarang diantara siswa sering meminta ijin keluar masuk kelas selama proses belajar mengajar berlangsung. Peran guru sangat dominan misalnya, guru yang mendefinisikan, menjelaskan, mendemonstrasikan, menyimpulkan, menerapkan prinsip-prinsip dan memberi tugas. Masalah diatas tidak bisa dibiarkan terus terjadi, siswa akan sulit membangun konsepnya sendiri dan mempelajari materi selanjutnya.

Kurikulum yang digunakan pada tahun ajaran 2016/2017 adalah Kurikulum 2013. Kurikulum ini menekankan pada keterlibatan siswa secara aktif dalam proses pembelajaran. Optimalisasi keterlibatan siswa dalam pembelajaran didukung dengan model pembelajaran yang kegiatan pembelajarannya berpusat pada siswa, sehingga siswa dapat menemukan suatu konsep terhadap apa yang dipelajarinya. Model pembelajaran inkuiri menawarkan keterlibatan siswa yang tinggi dalam proses pembelajaran sains. Model pembelajaran inkuiri, mempersiapkan siswa pada situasi untuk melakukan eksperimen sendiri secara luas agar melihat apa yang terjadi, ingin melakukan sesuatu, mengajukan pertanyaan-pertanyaan, dan mencari jawabannya sendiri. Berdasarkan National Research Council (2000) (dalam Zion, 2012) model pembelajaran inkuiri dikembangkan menjadi beberapa variasi seperti inkuiri terstruktur, inkuiri terbimbing dan inkuiri terbuka. Dalam penelitian ini dipergunakan model pembelajaran inkuiri terbimbing. Model pembelajaran tersebut, siswa diberikan kesempatan untuk bekerja merumuskan prosedur, menganalisis hasil dan mengambil kesimpulan secara mandiri, sedangkan dalam hal menentukan topik, pertanyaan dan bahan penunjang, guru hanya berperan sebagai fasilitator. Karena siswa belum terbiasa membangun sendiri pengetahuannya, menandakan bahwa siswa tersebut belum siap dibelajarkan dengan pembelajaran inkuiri. Oleh karena itu, model pembelajaran inkuiri terbimbing diperlukan sebagai pengantar siswa untuk siap selanjutnya menggunakan model pembelajaran inkuiri.

Menurut penelitian Mustachfidoh, et al (2013) tentang penerapan model pembelajaran inkuiri terbimbing untuk mengetahui hasil belajar, nilai rata-rata prestasi belajar sebesar 76, simpangan baku sebesar 9,39 dengan kategori baik dan rerata aktifitas belajar siswa yaitu 2,6 (tinggi). Hal ini menunjukan bahwa penggunaan model pembelajaran inkuiri terbimbing memberikan pengaruh yang signifikan terhadap aktifitas dan hasil belajar kimia siswa. Penerapan model pembelajaran yang berbeda dari model konvensional diharapkan dapat meningkatkan aktifitas dan hasil belajar siswa.

\section{Metode}

Penelitian ini merupakan Penelitian Tindakan Kelas (PTK) atau Classroom Action Research (CAR). PTK merupakan penelitian yang mengikutsertakan secara aktif peran guru dan siswa dalam berbagai tindakan. Daryanto (2011: 4) mengemukakan bahwa PTK adalah penelitian yang dilakukan oleh guru di dalam kelasnya sendiri melalui refleksi diri dengan tujuan untuk memperbaiki kualitas proses pembelajaran di kelas. Dalam penelitian ini, upaya memperbaiki kualitas proses pembelajaran dilakukan dengan penerapan model pembelajaran guided inquiry untuk meningkatkan aktivitas siswa dalam pembelajaran kimia pada siswa kelas X MIPA 4 SMA Negeri 3 Singaraja. Selain memperbaiki proses pembelajaran, penelitian ini bertujuan untuk meningkatkan hasil belajar kimia di kelas X MIPA 4 SMA Negeri 3 Singaraja. Pardjono, dkk. (2007: 37) mengemukakan bahwa yang menjadi fokus dalam PTK adalah proses bukan hasil. Penelitian ini memfokuskan pada tindakantindakan alternatif yang dibuat oleh peneliti. Tindakan yang dimaksud dalam penelitian ini adalah tindakan yang dilakukan secara sadar dan terkendali. Jadi tindakan yang dilakukan tersebut mengandung inovasi atau pembaharuan yang dapat memperbaiki kualitas pembelajaran.

Penelitian tindakan kelas ini dilaksanakan di SMA Negeri 3 Singaraja pada tahun ajaran 2016/2017, semester ganjil bulan September sampai Oktober 2016. Subjek dalam penelitian ini adalah siswa kelas X MIPA 4 yang berjumlah 26 orang yaitu 11 siswa laki-laki dan 15 siswa perempuan. Obyek penelitian ini adalah model pembelajaran guided inquiry, aktivitas siswa, dan hasil belajar siswa.

Pengumpuan data pada penelitian ini menggunakan rubric aktivitas belajar dan test hasil belajar. Instrumen penelitian yang digunakan adalah tes hasil belajar kimia. Tes hasil belajar dibuat dalam bentuk tes pilihan ganda dengan skor pada setiap butir adalah 1 (satu) jika menjawab benar dan mendapatkan skor 0 (nol) jika menjawab salah atau tidak menjawab. Langkah-langkah yang dilakukan dalam penyusunan tes hasil belajar adalah (1) mengidentifikasi kompetensi dasar, 
mengidentifikasi indikator pembelajaran, (3) menyusun kisi-kisi tes hasil belajar, (4) menentukan kriteria penilaian, (5) menyusun butir-butir tes, (6) bimbingan instrumen hasil belajar, (7) revisi, dan (8) finalisasi instrumen. Untuk rubrik tes pilihan ganda pada instrumen hasil belajar siswa yang menggunakan skala penilaian 0-1.

\section{Hasil}

Aktivitas Belajar.

Dari pelaksanaan awal penilaian keaktifan siswa dilakukan oleh guru lain yang membantu menilai kektifan siswa pada proses pembelajaran pada hari Jumat, 2 September 2016, diperoleh data bahwa keaktifan siswa dalam belajar terutama dalam mempelajari materi perkembangan model atom unsur masih tergolong kurang aktif. Untuk mengetahui tingkat keaktifan belajar siswa secara individual, data yang diperoleh dari rubrik penilaian dibandingkan dan dikonversikan dengan tabel konversi kemudian diubah dalam bentuk persentase. Secara rinci dapat diuraikan dalam tabel berikut.

Tabel 1. Data Aktivitas Belajar Siswa pada Awal Tindakan

\begin{tabular}{lcccccc}
\hline \multicolumn{1}{c}{ Indikator } & Siklus & $\begin{array}{c}\text { Pangat } \\
\text { aktif }\end{array}$ & Aktif & $\begin{array}{c}\text { Cukup } \\
\text { aktif }\end{array}$ & $\begin{array}{c}\text { Kurang } \\
\text { aktif }\end{array}$ & $\begin{array}{c}\text { Tidak } \\
\text { aktif }\end{array}$ \\
\hline $\begin{array}{l}\text { Antusiasme siswa dalam } \\
\text { proses pembelajaran }\end{array}$ & Awal & $0 \%$ & $7,5 \%$ & $0 \%$ & $2,5 \%$ & $90 \%$ \\
$\begin{array}{l}\text { Interaksi siswa dengan guru } \\
\text { Interaksi siswa dengan siswa }\end{array}$ & & $0 \%$ & $7,5 \%$ & $0 \%$ & $0 \%$ & $92,5 \%$ \\
\hline
\end{tabular}

Ketidakaktifan yang dilakukan oleh sebagian besar siswa adalah disebabkan karena rendahnya penguasaaan konsep pada pemahaman terhadap menjelaskan perkembangan teori atom. (Data keaktifan siswa pada awal tindakan secara lengkap disajikan dalam lampiran). Hasil perhitungan disajikan dalam grafik histogram berikut.

Hasil Penilaian Aktivitas Belajar siswa pada Siklus I menunjukkan bahwa sudah mengalami perubahan menjadi lebih baik. Secara umum siswa sudah aktif dalam beberapa indikator yang dijadikan pedoman. Secara rinci dapat diuraikan dalam tabel berikut.

Tabel 2. Data Penilaian Aktivitas Belajar Siswa pada Siklus I

\begin{tabular}{lcccccc}
\hline \multicolumn{1}{c}{ Indikator } & Siklus & $\begin{array}{c}\text { Sangat } \\
\text { aktif }\end{array}$ & $\begin{array}{c}\text { Aktif } \\
\text { Antakntif }\end{array}$ & $\begin{array}{c}\text { Kurang } \\
\text { aktif }\end{array}$ & $\begin{array}{c}\text { Tidak } \\
\text { aktif }\end{array}$ \\
\hline $\begin{array}{l}\text { Antusiasme siswa dalam } \\
\text { proses pembelajaran }\end{array}$ & Siklus I & $12,5 \%$ & $20 \%$ & $32,5 \%$ & $10 \%$ & $25 \%$ \\
$\begin{array}{l}\text { Interaksi siswa dengan guru } \\
\text { Interaksi siswa dengan siswa }\end{array}$ & & $10 \%$ & $22,5 \%$, & $30 \%$ & $12,5 \%$, & $25 \%$ \\
\hline
\end{tabular}

Berdasarkan hasil diskusi peneliti dengan teman sejawat (peneliti meminta salah seorang teman untuk membantu menilai keaktifan belajar siswa) maka pembelajaran dengan menggunakan model pembelajaran guided inquiry memang sangat mempengaruhi tingkat keaktifan belajar siswa. Hal ini disebabkan karena siswa secara langsung berinteraksi dan berbagi pengalaman dengan temannya. Namun ada juga beberapa orang siswa yang sama sekali tidak terlihat aktif dalam diskusi. Untuk itu, pengamat berharap agar penerapan model pembelajaran guided inquiry lebih dioptimalkan dan ditingkatkan strategi pelaksanaannya. (Data keaktifan belajar siswa pada pelaksanaan siklus I disajikan dalam lampiran). Hasil perhitungan disajikan dalam grafik histogram berikut.

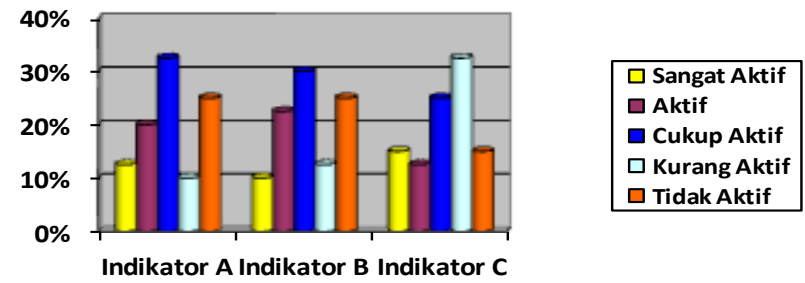

Grafik 01. Aktivitas Belajar Siswa Siklus I

Hasil Penilaian Aktivitas Belajar siswa pada Siklus II menunjukkan bahwa sudah mengalami perubahan yang sangat drastis. Secara umum hampir semua siswa sudah aktif dalam beberapa indikator yang dijadikan pedoman. Secara rinci dapat diuraikan dalam tabel berikut. 
Tabel 3. Data Penilaian Aktivitas Belajar Siswa pada Siklus II

\begin{tabular}{lcccccc}
\hline \multicolumn{1}{c}{ Indikator } & Siklus & $\begin{array}{c}\text { Sangat } \\
\text { aktif }\end{array}$ & Aktif & $\begin{array}{c}\text { Cukup } \\
\text { aktif }\end{array}$ & $\begin{array}{c}\text { Kurang } \\
\text { aktif }\end{array}$ & $\begin{array}{c}\text { Tidak } \\
\text { aktif }\end{array}$ \\
\hline $\begin{array}{l}\text { Antusiasme siswa dalam } \\
\text { proses pembelajaran }\end{array}$ & Siklus II & $25 \%$ & $37,5 \%$ & $25 \%$ & $7,5 \%$, & $5 \%$ \\
Interaksi siswa dengan guru & & $37,5 \%$ & $25 \%$ & $25 \%$ & $10 \%$ & $2,5 \%$. \\
Interaksi siswa dengan siswa & & $40 \%$ & $37,5 \%$ & $12,5 \%$ & $5 \%$ & $5 \%$ \\
\hline
\end{tabular}

Berdasarkan hasil diskusi peneliti dengan teman sejawat, pada siklus II penerapan model pembelajaran guided inquiry, prosesnya sudah berjalan secara efektif. Melalui pengalaman siswa yang secara langsung berinteraksi dan berbagi pengalaman dengan temannya, menyebabkan siswa memperoleh pengalaman dalam belajar dan menambah pengetahuan siswa sehingga dalam mengikuti diskusi siswa terlihat aktif. Walaupun ada satu atau dua orang siswa yang masih saja tidak aktif dalam proses pembelajaran, namun secara umum dapat disampaikan bahwa aktivitas kelas mengalami peningkatan sangat drastis jika dibandingkan dengan sebelum menerapkan pembelajaran dengan model pembelajaran guided inquiry. (Data dan perhitungan secara lengkap pelaksanaan siklus II disajikan dalam lampiran). Hasil perhitungan disajikan dalam grafik histogram berikut.

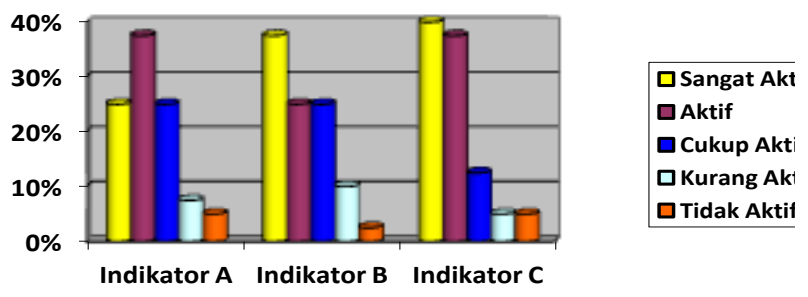

Grafik 02. Aktivitas Belajar Siswa Siklus II

Berdasarkan data aktifitas belajar siswa di atas jika dibandingkan dengan aktifitas belajar siswa pada akhir siklus I dengan akhir siklus II, aktifitas siswa di kelas mulai meningkat. Untuk mendapat gambaran lebih jelas mengenai aktifitas belajar siswa dari refleksi awal, siklus I, sampai siklus II, maka ditampilkan ringkasannya pada tabel berikut.

Tabel 4. Data Penilaian Aktivitas Belajar Siswa pada tahap awal tindakan-akhir siklus II

\begin{tabular}{|c|c|c|c|c|c|c|}
\hline \multirow[t]{2}{*}{ Indikator } & \multirow[t]{2}{*}{ Siklus } & \multicolumn{5}{|c|}{ Perentase keaktifan siswa } \\
\hline & & $\begin{array}{c}\text { Sangat } \\
\text { aktif }\end{array}$ & Aktif & $\begin{array}{l}\text { Cukup } \\
\text { aktif }\end{array}$ & $\begin{array}{c}\text { Kurang } \\
\text { aktif }\end{array}$ & $\begin{array}{l}\text { Tidak } \\
\text { aktif }\end{array}$ \\
\hline Antusiasme & Awal & $0 \%$ & $7,5 \%$ & $0 \%$ & $2,5 \%$ & $90 \%$ \\
\hline siswa dalam & Siklus I & $12,5 \%$ & $20 \%$ & $32,5 \%$ & $10 \%$ & $25 \%$ \\
\hline proses & Siklus II & $25 \%$ & $37,5 \%$ & $25 \%$ & $7,5 \%$ & $5 \%$ \\
\hline pembelajaran & & & & & & \\
\hline Interaksi & Awal & $0 \%$ & $7,5 \%$ & $0 \%$ & $0 \%$ & $92,5 \%$ \\
\hline siswa dengan & Siklus I & $10 \%$ & $22,5 \%$ & $30 \%$ & $12,5 \%$ & $25 \%$ \\
\hline guru & Siklus II & $37,5 \%$ & $25 \%$ & $25 \%$ & $10 \%$ & $2,5 \%$. \\
\hline Interaksi & Awal & $0 \%$ & $5 \%$ & $0 \%$ & $2,5 \%$ & $92,5 \%$ \\
\hline siswa dengan & Siklus I & $15 \%$ & $12,5 \%$ & $25 \%$ & $32,5 \%$ & $15 \%$ \\
\hline siswa & Siklus II & $40 \%$ & $37,5 \%$ & $12,5 \%$ & $5 \%$ & $5 \%$ \\
\hline
\end{tabular}

\section{Hasil Belajar Siswa}

Berdasarkan data hasil belajar di atas jika dibandingkan dengan hasil tes akhir siklus I dapat dijelaskan bahwa pada siklus II ini semua siswa nilainya sudah meningkat drastis, 28 orang siswa $(100 \%)$ nilainya sudah tuntas. Nilai tertinggi yang dicapai yaitu 90 dan terendah 75 .
Untuk mendapat gambaran lebih jelas tentang adanya peningkatan kemampuan, daya serap, dan ketuntasan hasil belajar pada tes awal dan tes akhir baik itu pada siklus I maupun siklus II, maka ditampilkan ringkasannya pada tabel 16 berikut. 
Tabel 5. Ringkasan Analisis Data Tes Awal dengan Tes Akhir Siklus I - II

\begin{tabular}{|c|c|c|c|c|c|c|c|c|}
\hline \multirow{3}{*}{ No } & \multirow{2}{*}{\multicolumn{3}{|c|}{ Tes Awal }} & \multicolumn{4}{|c|}{ Tes Akhir } & \multirow{3}{*}{ Ket } \\
\hline & & & & \multicolumn{2}{|c|}{ Siklus I } & \multicolumn{2}{|c|}{ Siklus II } & \\
\hline & Tes & $\begin{array}{c}\text { Freku } \\
\text { ensi }\end{array}$ & Jml Nilai & $\begin{array}{c}\text { Frekuen } \\
\mathrm{si}\end{array}$ & Jml Nilai & $\begin{array}{c}\text { Frekuen } \\
\text { si }\end{array}$ & $\begin{array}{c}\text { Jml } \\
\text { Nilai }\end{array}$ & \\
\hline 1 & 30 & 1 & 30 & & & & & \\
\hline 1 & 40 & 8 & 320 & 1 & 40 & - & - & BT \\
\hline 2 & 45 & & & 1 & 45 & - & - & BT \\
\hline 3 & 50 & 12 & 600 & 5 & 250 & - & - & BT \\
\hline 4 & 55 & & & 6 & 330 & - & - & BT \\
\hline 5 & 60 & 3 & 180 & 4 & 240 & - & - & BT \\
\hline 6 & 65 & & & 2 & 130 & 2 & 130 & $\mathrm{~T}$ \\
\hline 7 & 70 & 9 & 630 & 11 & 770 & 8 & 560 & $\mathrm{~T}$ \\
\hline 8 & 75 & & & 7 & 525 & 10 & 750 & $\mathrm{~T}$ \\
\hline 9 & 80 & 2 & 160 & 2 & 160 & 10 & 800 & $\mathrm{~T}$ \\
\hline 10 & 85 & - & - & 1 & 85 & 4 & 340 & $\mathrm{~T}$ \\
\hline \multirow[t]{6}{*}{11} & 90 & - & - & - & - & 6 & 540 & $\mathrm{~T}$ \\
\hline & $\mathrm{N}=$ & 28 & & 28 & - & 28 & - & \\
\hline & \multicolumn{2}{|c|}{$\sum X$} & 2220 & & 2575 & & 3120 & \\
\hline & \multicolumn{2}{|c|}{ Rata-rata Kelas } & 55,50 & & 64,37 & & 78 & \\
\hline & \multicolumn{2}{|c|}{ Daya Serap (\%) } & $55,50 \%$ & & $64,37 \%$ & & $78 \%$ & \\
\hline & \multicolumn{2}{|c|}{ Ketuntasan (\%) } & $27,50 \%$ & & $56,10 \%$ & & $100 \%$ & \\
\hline
\end{tabular}

Adanya peningkatan rata-rata, daya serap, dan ketuntasan prestasi belajar pada tes awal dan tes akhir baik itu pada siklus I maupun siklus II juga dapat diamati pada grafik histogram berikut ini.

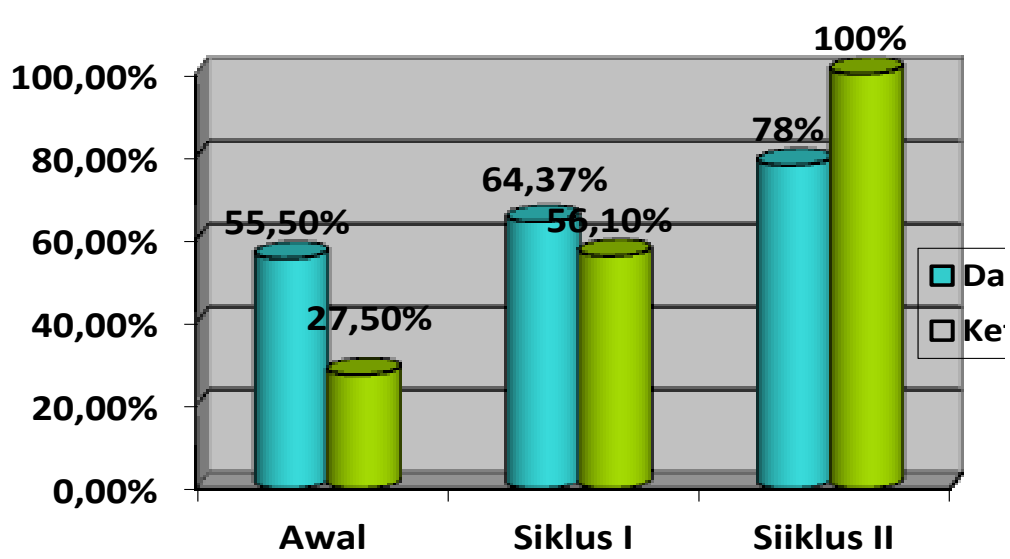

Grafik 03. Peningkatan Daya Serap Dan

Ketuntasan Belajar Tes Awal Dengan Tes Akhir Pada Siklus I - II

\section{Pembahasan}

Berdasarkan hasil observasi aktivitas siswa sebelum dilakukannya tindakan menunjukkan bahwa aktivitas siswa kelas X MIPA 4 SMA Negeri 3 Singaraja masih rendah. Permasalahan tersebut merupakan salah satu permasalahan yang peneliti temukan pada saat observasi awal. Siswa cenderung pasif dalam pembelajaran dikelas. Proses pembelajaran IPA khususnya kimia seharusnya menekankan siswa aktif mencari dan menemukan sendiri suatu konsep.
Guru berperan sebagai pembimbing yang mengarahkan siswa dalam upaya memperoleh suatu pengetahuan. Proses pembelajaran seharusnya melibatkan siswa untuk aktif dalam setiap kegiatan pembelajaran yang meliputi aktivitas mengamati, mengajukan pertanyaan, mendengarkan penjelasan guru, mengemukakan pendapat, mengajukan berbagai kemungkinan pemecahan masalah, melakukan percobaan, menemukan jawaban berdasarkan hasil percobaan dan merumuskan kesimpulan.

Pemilihan metode yang tepat menjadi salah satu faktor yang berpengaruh terhadap aktivitas siswa dalam pembelajaran kimia. Salah satu metode yang dapat diterapkan dalam pembelajaran kimia di SMA adalah model pembelajaran guided inquiry.

Wina Sanjaya (2009: 196) mengemukakan bahwa ciri utama dalam penerapan model pembelajaran guided inquiry yakni dalam prosesnya lebih menekankan kepada aktivitas siswa secara maksimal untuk mencari dan menemukan, artinya menempatkan siswa sebagai subjek belajar. Model pembelajaran guided inquiry memberikan kesempatan kepada siswa untuk aktif terlibat dalam pemecahan masalah melalui langkah-langkah yang sistematis. Adapun langkah-langkah penerapan metode guided inquiry dalam pembelajaran kimia di SMA meliputi 1) orientasi, 2) merumuskan masalah, 3) merumuskan hipotesis sederhana, 4) mengumpulkan data, 5) menguji hipotesis, dan 6) merumuskan kesimpulan.

Proses pembelajaran pada siklus I menunjukkan adanya peningkatan aktivitas siswa dalam pembelajaran kimia. Siswa aktif 
dalam aktivitas mengamati, mendengarkan penjelasan guru, mengemukakan pendapat, mengajukan berbagai kemungkinan pemecahan masalah dan menulisnya, memilih alat dan bahan, melakukan percobaan berdasarkan langkah kerja yang ditentukan, mencatat data hasil pengamatan, menggambar objek pengamatan/hasil percobaan, menemukan jawaban berdasarkan hasil percobaan dan merumuskan kesimpulan. Guru berperan sebagai pembimbing yang mengarahkan siswa dalam aktivitas pembelajaran.

Berdasarkan hasil observasi dan skala aktivitas siswa pada siklus I menunjukkan belum tercapainya kriteria keberhasilan yang ditentukan. Aspek aktivitas siswa yang belum tercapai berdasarkan kriteria keberhasilan di siklus I yaitu pada aspek orientasi, merumuskan hipotesis sederhana, dan merumuskan kesimpulan. Secara umum dalam penelitian ini kegiatan siswa yang belum meningkat adalah 1) mengajukan pertanyaan, 2) mengemukakan pendapat dalam diskusi, 3) mengajukan rumusan hipotesis sederhana, dan 4) mengemukakan rumusan kesimpulan hasil percobaan. Pada tahap orientasi, seluruh siswa tidak ada satupun yang mengajukan pertanyaan baik mengenai hal-hal yang belum dipahami maupun hal-hal yang ingin siswa ketahui. Hal tersebut dikarenakan kurangnya rasa ingin tahu siswa terhadap pembelajaran. Siswa cenderung memiliki rasa percaya diri yang rendah. Sebagian besar siswa tidak mengemukakan pendapatnya dalam diskusi, hanya beberapa siswa yang terlihat aktif. Selain itu siswa belum dapat mengajukan rumusan hipotesis sederhana dan mengemukakan rumusan kesimpulan hasil percobaan dengan baik karena belum terbiasa dan merupakan hal yang baru bagi siswa sehingga guru perlu memberikan bimbingan dalam upaya merumuskan hipotesis sederhana dan merumuskan kesimpulan hasil percobaan.

Dengan melihat hasil yang diperoleh pada pelaksanaan tindakan penelitian pertemuan pertama, kedua, dan ketiga maka peneliti memutuskan untuk melaksanakan rencana tindak lanjut pada siklus II. Tindakan yang diputuskan untuk diperbaiki yaitu pada aspek orientasi, merumuskan hipotesis sederhana, dan merumuskan kesimpulan. Pemberian penghargaan dapat merangsang dan menumbuhkan motivasi siswa untuk aktif terlibat dalam setiap aktivitas pembelajaran.

Selanjutnya berdasarkan proses pembelajaran pada siklus II menunjukkan adanya peningkatan hasil belajar kimia. Hal tersebut dapat dilihat dari persentase ketuntasan belajar siswa .Hasil belajar pada siklus II mengenai materi ikatan ion dan ikatan kovalen mengalami peningkatan ketuntasan yaitu dari $56 \%$ pada siklus I menjadi $100 \%$ pada siklus II. Berdasarkan pembahasan tersebut terbukti bahwa melalui model pembelajaran guided inquiry dapat meningkatkan aktivitas dan hasil belajar kimia di kelas X MIPA 4 SMA Negeri 3 Singaraja.

\section{Penutup}

Berdasarkan analisis data diketahui bahwa telah terjadi peningkatan aktivitas belajar kimia dan peningkatan hasil belajar kimia siswa. Hasil belajar dari kondisi awal ke kondisi akhir mengalami peningkatan. Nilai rerata yang dicapai peserta didik pada kondisi awal sebesar 55,50 menjadi 68 pada siklus I dan meningkat menjadi 78,00 pada siklus II sehingga dari kondisi awal ke kondisi akhir peningkatan nilai rerata peserta didik sebesar 22,5\%. Jumlah peserta didik yang mencapai kriteria ketuntasan minimal (KKM) dari kondisi awal ke kondisi akhir mengalami peningkatan. Jumlah peserta didik yang mencapai KKM pada kondisi awal sebanyak 8 peserta didik atau sebesar 27,5\% menjadi 16 peserta didik atau sebesar $57 \%$ pada siklus I dan meningkat menjadi 28 peserta didik atau sebesar $100 \%$ pada siklus II. Dengan demikian dari kondisi awal ke kondisi akhir peningkatan jumlah peserta didik yang mencapai KKM sebesar 72,5\%.

\section{Daftar Pustaka}

Akbar, Sa'dun. 2010. Penelitian Tindakan Kelas (Edisi Revisi). Yogyakarta: Cipta Media.

Arikunto, S. 2007. Dasar-Dasar Evaluasi Pendidikan (Edisi Revisi). Jakarta: Bumi Aksara.

Dahar, R. W. (1996). Teori-teori belajar. Jakarta: Erlangga.

Depdiknas. 2006. Kurikulum Tingkat Satuan Pendidikan Ilmu Pengetahuan Alam untuk Sekolah Menengah Pertama. Jakarta: Depdiknas.

Djamarah, Syaiful Bahri. 2000. Strategi Belajar Mengajar. Banjarmasin: Rineka Cipta.

Emzir. 2007. Metode Penelitian Pendidikan Kuantitatif dan Kualitatif. Jakarta: Grafindo.

Gulo, W. 2002. Strategi Belajar-Mengajar. Jakarta: PT Grasindo.

Hamalik, Oemar. 2001. Proses Belajar Mengajar. Jakarta : Bumi Aksara.

Hermawati, M. N. W. 2012. "Pengaruh Model Pembelajaran Inkuiri Terhadap Penguasaan Konsep Biologi dan Sikap Ilmiah Siswa SMA Ditinjau dari Minat Belajar Siswa". Tersedia pada http://pasca.undiksha.ac.id/e-journal/ index.php/jurnal_ipa/article/download 
/488/280. (diakses tanggal 14 Juni 2013)

Joyce, B., et al. 2009. Model-Model Pengajaran (Edisi kedelapan). Terjemahan Achmad Fawaid dan Ateilla Mirza. Models of Teaching. Yogyakarta: Pustaka Pelajar.

Kerlinger, F. N. (2000). Asas-asas penelitian behavioral. Terjemahan: Fondation Behavioral Research, oleh: Simatupang, L. R. \& Koesoemanto, H. J. Yogyakarta: gajah Mada University Press.

Kuhkthau, C.C., \& Todd, R.J. 2006. "Guided Inquiry: A Framework for learning Troug School Lobraries in 21th Century School". Tersedia pada http://cissl.scills.rutger.edu/guidedinqu iry/char.htm. (diakses tanggal 1 Maret 2013)

Margono, S. 2005. Metodologi Penelitian Pendidikan. Jakarta: PT. Rineka Cipta.

Mulyasa. 2007. Menjadi Guru Profesional Menciptalan Pembelajaran Kreatif dan Menyenangkan. Bandung: PT Remaja Rosdakarya.

Rusefendi. 2005. Dasar-dasar Penelitian Pendidikan dan Bidang Eksakta Lainnya. Bandung: Tarsito.

Sanjaya, W. 2008. Pembelajaran Berorientasi Standar Proses Pendidikan. Jakarta: Kencana.

Sudria, I. B. N. 2006. Pengembangan Materi Pembelajaran Kimia di SMP dalam Rangka Pendidikan "Science For All". Disertasi (tidak diterbitkan). Bandung: Sekolah Pasca Sarjana Universitas Pendidikan Indonesia.

Trianto. 2010. Model-model pembelajaran inovatif berorientasi konstruktivitis. Jakarta:Prestasi Pustaka.

Tuckman, B. W. 1999. Conducting Education Research. Fifth Edition. New York: Harcourt Brace College.

Udijono, A. 2007. Pengantar Evaluasi Pendidikan. Jakarta: PT Raja Grafindo Persada.

Zulfiani. 2006. Pengembangan Model Pembelajaran Inkuiri untuk Calon Guru pada Konsep Bioteknologi. Bandung: UPI Bandung.

Zion, M., \& Mendelovici, R. 2012. "Moving from Structured to Open Inquiry". Journal of Science Education International, 23(4). 383-399. 